\title{
Correction: Mahler et al. Preservice Biology Teachers' Scientific Reasoning Skills and Beliefs about Nature of Science: How Do They Develop and Is There a Mutual Relationship during the Development? Educ. Sci. 2021, 11, 558
}

\author{
Daniela Mahler $^{1,2, *,+}+\mathbb{D}$, Denise Bock ${ }^{2}$ (D) and Till Bruckermann ${ }^{3, *,+}+\mathbb{D}$ \\ 1 Biology Education, Freie Universität Berlin, 14195 Berlin, Germany \\ 2 IPN_Leibniz Institute for Science and Mathematics Education, 24118 Kiel, Germany; bock@leibniz-ipn.de \\ 3 Institute of Education, Leibniz University Hannover, 30167 Hannover, Germany \\ * Correspondence: daniela.mahler@fu-berlin.de (D.M.); till.bruckermann@iew.uni-hannover.de (T.B.) \\ + These authors contributed equally to this work.
}

check for

updates

Citation: Mahler, D.; Bock, D.;

Bruckermann, T. Correction: Mahler et al. Preservice Biology Teachers' Scientific Reasoning Skills and Beliefs about Nature of Science: How Do They Develop and Is There a Mutual Relationship during the Development? Educ. Sci. 2021, 11, 558. Educ. Sci. 2022, 12, 21. https:// doi.org/10.3390/educsci12010021

Received: 3 December 2021

Accepted: 3 December 2021

Published: 30 December 2021

Publisher's Note: MDPI stays neutral with regard to jurisdictional claims in published maps and institutional affiliations.

Copyright: (C) 2021 by the authors. Licensee MDPI, Basel, Switzerland. This article is an open access article distributed under the terms and conditions of the Creative Commons Attribution (CC BY) license (https:// creativecommons.org/licenses/by/ $4.0 /)$.

\section{Error in Figure}

In the original version of the paper [1], a regression weight was assigned to the wrong cross-lagged path in Figure 1 (bottom). In the original version, the regression weight $(B=-0.22)$ was assigned to the cross-lagged path between scientific methods (MET) at semester 3 and scientific reasoning (SR) skills at semester 5 . In the correct version, the regression weight $(B=-0.22)$ is assigned to the cross-lagged path between SR skills at semester 3 and MET at semester 5 . A correct version of the figure can be taken from this correction. This correction does not change the conclusions drawn in the article, as the text portions of the manuscript correctly report the regression weights. Also, we would like to apologize for any inconvenience this change may have caused.

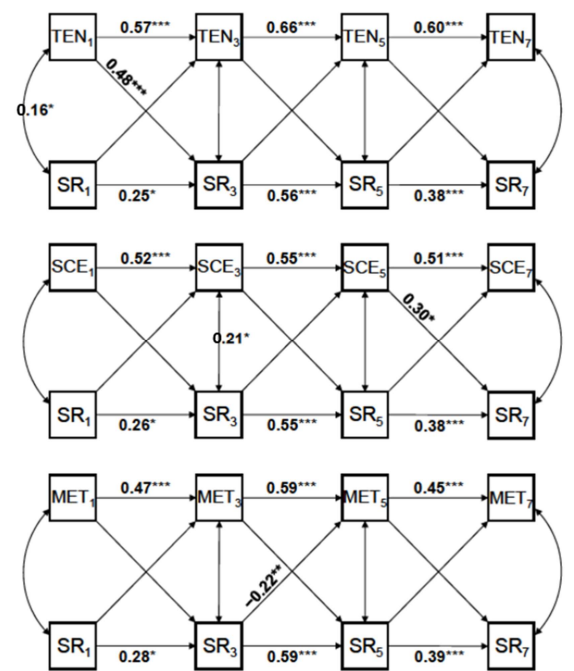

Figure 1. Unstandardized regression weights for (auto-)regression paths of cross-lagged models computed for scientific reasoning and nature of science subscales; tentativeness, TEN; social and cultural embeddedness, SCE; and scientific methods, MET; numbers in subscript refer to the respective semester; ${ }^{*} p<0.05,{ }^{* *} p<0.01,{ }^{* * *} p<0.001$.

\section{Reference}

1. Mahler, D.; Bock, D.; Bruckermann, T. Preservice Biology Teachers' Scientific Reasoning Skills and Beliefs about Nature of Science: How Do They Develop and Is There a Mutual Relationship during the Development? Educ. Sci. 2021, 11, 558. [CrossRef] 